\title{
Literature Review Penerapan Teknologi Informasi dan Metode Pengukuran Pada Audit Kepuasan Pelanggan
}

\author{
Charolina Devi Oktaviana $\mathrm{S}^{1}$, I Nyoman Pramaita ${ }^{2}$, Made Sudarma ${ }^{3}$ \\ [Submission: 04-06-2021, Accepted: 13-08-2021]
}

\begin{abstract}
Customer loyalty is very important in the sustainability of a business, to maintain customer loyalty, companies are required to understand the level of customer satisfaction and complaints that arise in the service delivery process, manual questionnaires will prevent companies from obtaining customer satisfaction measurement results quickly and accurately. The faster development of information technology is expected to be able to assist companies in the customer satisfaction audit process, both from the process of distributing questionnaires and processing customer satisfaction measurement data, the results of the literature study show that the application of information technology combined with methods in customer satisfaction audits can help companies in obtaining information related to the results of measuring customer satisfaction quickly and with ease of access, so that stakeholders in the company can take corrective actions to resolve complaints. customer satisfaction and increased performance improvement according to the level of customer satisfaction, from the research results obtained $92 \%$ of websitebased technology is still widely used in the customer satisfaction audit process and $39 \%$ of the CSI method is the method most often applied for measuring customer satisfaction.
\end{abstract}

Key Words - Audit, Customer Satisfaction, Implementation Information technology, Method.

Intisari- Loyalitas pelanggan adalah hal yang sangat penting dalam keberlangsungan suatu usaha, untuk mempertahankan loyalitas pelanggan, perusahaan dituntut untuk memahami tingkat kepuasan pelanggan dan keluhan yang timbul dalam proses pemberian layanan, penyebaran kuesioner secara manual akan menghambat perusahaan untuk memperoleh hasil pengukuran kepuasan pelanggan secara cepat dan akurat, perkembangan teknologi informasi yang semakin cepat diharapkan mampu untuk membantu perusahaan dalam proses audit kepuasan pelanggan, baik dari proses penyebaran kuesioner dan pengolahan data hasil pengukuran kepuasan pelanggan, hasil dari studi literature diketahui bahwa penerapan teknologi informasi yang dikombinasikan dengan metode dalam audit kepuasan pelanggan dapat membantu perusahaan dalam memperoleh informasi terkait dengan hasil pengukuran kepuasan pelanggan secara cepat dan kemudahan dalam akses, sehingga pemangku kepentingan pada perusahaan dapat mengambil tindakan perbaikan untuk mengatasi keluhan pelanggan dan peningkatan perbaikan kinerja sesuai pada tingkat kepuasan pelanggan.

${ }^{1}$ Mahasiswa, Magister Teknik Elektro Universitas Udayana, Gedung Pascasarjana Universitas Udayana Jl. PB Sudirman Denpasar-Bali, Kode Pos: 80232; (tlp/fax: 0361-239599; e-mail: devicharolina@gmail.com)

2, 3 Dosen, Magister Teknik Elektro Universitas Udayana, Gedung Pascasarjana Universitas Udayana Jl. PB Sudirman Denpasar-Bali, Kode Pos: 80232; (tlp/fax: 0361-239599; e-mail: 2pramaita@ee.unud..ac.id, ${ }^{3}$ sudarma@unud.ac.id)

Charolina Devi Oktaviana S: Literature Review Penerapan ...
Dari hasil penelitian diperoleh $92 \%$ teknologi berbasis website masih banyak digunakan dalam proses audit kepuasan pelanggan dan $39 \%$ metode CSI merupakan metode yang paling sering diterapkan untuk pengukuran kepuasan pelanggan.

Kata Kunci-Audit, Implementasi, Kepuasan Pelanggan, Metode, Teknologi informasi.

\section{PENDAHULUAN}

Loyalitas pelanggan merupakan salah satu kunci dalam keberhasilan perkembangan bisnis perusahaan, tidak hanya akan mendatangkan suatu pelanggan yang baru namun dapat meningkatkan suatu profitabilitas perusahaan [1] keberhasilan perusahaan dalam mengelola keluhan pelanggan akan membantu perusahaan dalam memperbaiki kinerja perusahaan secara tepat.

Kepuasan pelanggan merupakan salah satu faktor yang dapat meningkatkan loyalitas pelanggan selain itu dengan kepuasan pelanggan akan dapat meminimalkan kegagalan dalam strategi pemasaran perusahaan karena hubungan yang terbentuk antara perusahaan dan pelanggan [2]. Berdasarkan Penelitian [3] Tingginya tingkat persaingan antar kompetitor saat ini menjadikan pelanggan memiliki berbagai alternatif pilihan baik dari segi harga dan kualitas yang bervariasi dalam penggunaan barang atau jasa dalam memenuhi kebutuhan baik secara individual atau perusahaan.

Kemajuan teknologi informasi saat ini turut berpartisipasi dalam perkembangan proses bisnis, kemudahan dalam akses yang diberikan membantu perusahaan untuk mendapatkan informasi baik melalui website maupun mobile celluar yang dimiliki, potensi kemudahan yang diberikan oleh perkembangan teknologi informasi akan lebih optimal apabila diterapkan secara tepat pada proses bisnis perusahaan, terlebih lagi dalam hal membantu pengambilan keputusan untuk perbaikan perusahaan kedepannya.

Hasil pengukuran audit kepuasan pelanggan memiliki peranan yang penting dalam menentukan strategi perusahaan pada perbaikan kinerja khususnya dalam meningkatkan pelayanan yang diberikan kepada pelanggan dan mengatur tingkat produktifitas kinerja perusahaan. Pengukuran terhadap kepuasan pelanggan dapat dilakukan dengan berbagai cara baik secara interview langsung bertemu dengan pelanggan ataupun dengan menggunakan sistem untuk mempermudah dalam memperoleh data kepuasan pelanggan dan mengolahnya menjadi suatu informasi yang dapat digunakan untuk perbaikan kinerja suatu perusahaan..

Pengolahan data hasil dari survey kepuasan pelanggan secara independen akan menghasilkan suatu informasi yang tepat dalam pengambilan keputusan untuk menentukan

$$
\text { p-ISSN:1693 - 2951; e-ISSN: 2503-2372 }
$$


perbaikan kinerja perusahaan, Penelitian ini bertujuan untuk mengetahui penerapan teknologi informasi dalam proses audit kepuasan pelanggan dan bagaimana hasil dari penerapan teknologi dengan metode pengukuran tingkat kepuasan pelanggan sehingga dapat menghasilkan rekomendasi perbaikan yang sesuai dengan keluhan pelanggan dalam perbaikan bekelanjutan.

\section{LITERATURE REVIEW}

\section{A. Kepuasan Pelanggan}

Kepuasan pelanggan merupakan suatu titik puncak dari usaha yang dihasilkan oleh perusahaan baik yang bergerak pada bidang pelayanan jasa dan produk dimana produk yang dihasilkan diharapkan memiliki nilai yang tinggi dan memenuhi dari harapan pelanggan [4]. Perbandingan dari kepuasan dan ketidakpuasan pelanggan terhadap penggunaan barang/jasa dapat digambarkan perbandingan antara kesesuaian dari aktual dan harapan pelanggan terhadap barang/jasa, ditunjukan pada Gambar 1 .

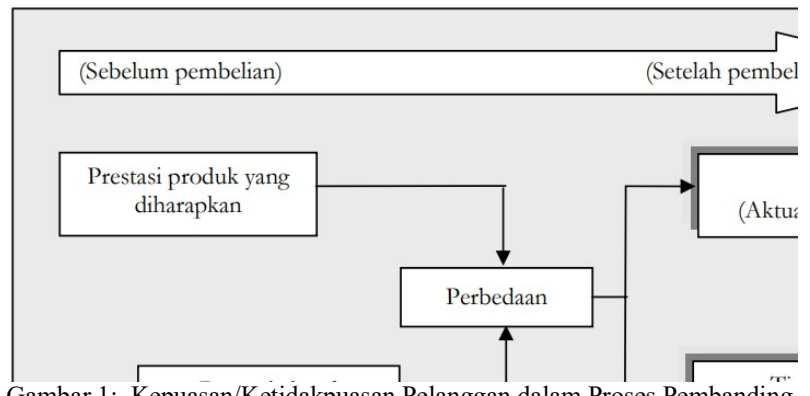

Gambar 1: Kepuasan/Ketidakpuasan Pelanggan dalam Proses Pembanding.

Kepuasan pelanggan dapat mempengaruhi loyalitas terhadap penggunaan pelayanan jasa yang diberikan maka pengukuran terhadap hal tersebut penting untuk dilakukan. Ada 4 indikator yang digunakan dalam melakukan pengukuran kepuasan pelanggan antara lain [5];

- Sistem Keluhan dan Saran

Perusahaan yang memiliki keterikatan yang kuat kepada pelanggan sangat penting untuk mengutamakan pendapatan, keluhan atau kritik dari pelanggan untuk memperbaiki dan membangun hubungan yang baik dengan pelanggan, hal ini dapat dilakukan dengan memberikan ruang kepada pelanggan untuk menyampaikan keluhan dan saran pada media yang disediakan oleh pelanggan.

- Survey Kepuasan Pelanggan

Pada umumnya survey kepuasan pelanggan telah dilakukan oleh berbagai perusahaan baik dengan melalui wawancara, telepon atau mengisi kuesioner, dengan melalukan survey perusahaan akan mendapatkan respon langsung dari pelanggan baik positif ataupun negatif dalam memperbaiki pelayanan yang dimiliki. Ada beberapa metode yang digunakan dalam melakukan survey kepuasan pelanggan yaitu

a. Directly report satisfaction yaitu pengukuran langsung melalui pertanyaan. b. Derived disatisfaction yaitu pertanyaan yang berkaitan dengan harapan pelanggan terhadap pelayanan.

c. Problem Analysis yaitu menganalisa pelanggan terhadap masalah - masalah yang dihadapi saat proses pelayanan dan saran yang ingin disampaikan.

d. Importance performance analysis yaitu pelanggan diminta untuk melakukan perangkingan dari element mana saja yang paling penting untuk pelanggan pada saat proses pelayanan jasa.

\section{- $\quad$ Ghost Shopping}

Ghost Shopping adalah suatu metode dengan menggunakan beberapa orang untuk menjadi pembeli bayaran pada perusahaan lain untuk menyampaikan kekurangan dari pesaing perusahaan.

- $\quad$ Lost Customer Analysis

Menghubungi kembali pelanggan yang sebelumnya menggunakan jasa kemudian beralih atau berhenti membeli untuk mengetahui penyebab terhentinya proses bisnis.

\section{B. Teknologi Informasi}

Teknologi informasi merupakan suatu kemajuan perkembangan dunia teknologi yang dapat memberikan kemudahan dalam pengelolaan data, dengan pengolahan data yang bersifat transparansi, efisiensi dan efektifitas, akan menghasilkan suatu informasi yang tepat dan akurat. Penelitian [6] menjelaskan dengan penerapan teknologi informasi secara optimal dapat membantu dalam peningkatan kinerja suatu lembaga atau organisasi, dimana teknologi informasi akan memberikan kemudahan dalam pengelolaan dan pengolahan data secara cepat, meminimalkan kesalahan dalam pemrosesan data, serta pengelolaan data yang terstruktur.

\section{Audit}

Audit merupakan suatu kegiatan untuk melakukan evaluasi mengukur kesesuaian dari kinerja suatu proses terhadap prosedur yang dimiliki atau yang telah teruji, Penelitian [7] melakukan penerapan audit terhadap suatu sistem informasi dengan menggunakan COBIT 5 diketahui bahwa penerapan audit sistem informasi pada lembaga dapat menghasilkan suatu ukuran kesesuaian antara kinerja yang telah berjalan dengan ukuran standar yang diharapkan, hal ini dapat membantu perusahaan dalam mengkoreksi kembali suatu kinerja baik layanan secara nyata ataupun sistem yang diterapkan untuk mengoptimalkan kinerja dan proses yang berjalan pada suatu lembaga atau organisasi.

\section{METODELOGI PENELITIAN}

Pada penelitian ini dilakukan studi literature terkait dengan penerapan sistem pada audit kepuasan untuk membantu perusahaan dalam mengambil keputusan perbaikan dalam proses bisnis. Penelitian ini bertujuan untuk mengetahui penggunaan sistem dalam proses audit kepuasan pelanggan dan penggunaan metode dalam sistem untuk mengukur tingkat kepuasan pelanggan sehingga dapat menghasilkan pendukung keputusan yang sesuai dengan keluhan pelanggan dalam 
DOI: https://doi.org/10.24843/MITE.2021.v20i02.P13

perbaikan bekelanjutan. schematic penelitian ditunjukan pada Gambar 2.

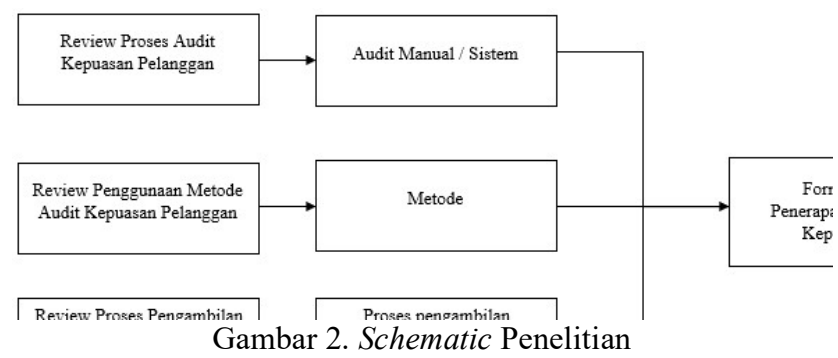

Pada schematic penelitian memiliki beberapa tahapan yaitu melakukan review pada proses audit yang dilakukan dengan penerapan sistem atau secara tradisional untuk mengetahui proses audit yang dilakukan, tahapan kedua yaitu melakukan review studi literature terhadap metode audit yang digunakan dalam proses audit kepuasan pelanggan, hal ini dilakukan untuk mengetahui metode yang banyak digunakan dan proses dalam penggunaan metode tersebut, tahapan ketiga yaitu melakukan review terhadap proses pengambilan keputusan dalam mengatasi permasalahan kepuasan pelanggan dalam pengambilan keputusan dilakukan secara tradisional atau menggunakan sistem secara otomatis.

\section{HASIL DAN PEMBAHASAN}

Pada penelitian ini akan membahas terkait dengan penerapan teknologi informasi pada audit kepuasan pelanggan dan metode yang digunakan selama proses analisa untuk mendukung pengambilan keputusan terkait dengan permasalahan kepuasan pelanggan yang ada pada proses bisnis. Penelitian dilakukan dengan menggunakan mesin pencarian google scholar dengan kata kunci : Penerapan teknologi pada analisa kepuasan pelanggan, Sistem pendukung keputusan analisa kepuasan pelanggan, teknologi informasi pada survey kepuasan pelanggan. Berdasarkan kata kunci diperoleh 24 dokumen terkait dengan penerapan teknologi informasi pada audit kepuasan pelanggan, hasil dari penelitian dijelaskan secara lebih detail pada dokumen dibawah ini

\section{A. Penerapan Sistem dan Metode dalam Audit Kepuasan Pelanggan}

Penelitian [8] Kepuasan pelanggan adalah komponen yang penting dalam meningkatkan pelayanan kepada pelanggan, dengan melakukan audit kepuasan pelanggan maka diharapkan perusahaan dapat mengetahui tingkat kepuasan pelanggan terhadap produk yang dijual kepada pelanggan, untuk mengukur tingkat kepuasan pelanggan pada penjualan perusahaan sepeda motor dilakukan pengukuran dengan menggunakan metode preference ranking oragizational method for enrichment evaluation, proses penelitian dilakukan dengan mengunakan sistem berbasis website melalui pembagian angket pada pelanggan yang terkait dengan indikator penilaian tingkat kesesuaian antara produk dan harapan pelanggan, dari hasil penelitian diperoleh tingkat kepuasan pelanggan tertinggi pada salah satu produk sepeda motor, sistem pendukung keputusan diterapkan untuk Charolina Devi Oktaviana S: Literature Review Penerapan ... menentukan tingkat kepuasan pelanggan dengan sistem ranking atau skala prioritas pada produk yang disediakan berdasarkan indikator yang menjadi penilaian dari setiap produk untuk menghasilkan sebuah rekomendasi yang objektif dan otomatis.

Penelitian [9] Kemampuan perusahaan dalam memahami kebutuhan pelanggan merupakan salah satu kunci keberhasilan perusahaan khususnya mampu dalam mengambil keputusan perbaikan yang menimbulkan ketidakpuasan pelanggan dalam pelayanan, pada penelitian ini pengukuran kepuasan pelanggan dilakukan dengan penerapan teknologi informasi dalam audit kepuasan pelanggan, dari hasil penelitian diperoleh penggunaan sistem informasi pada PT. Bank Maluku memberikan kemudahan bagi pelanggan dalam menyampaikan saran terhadap pelayanan, dengan fitur pengisian kuesioner yang mudah digunakan dan pemberikan nilai berdasarkan skala linkert memudahkan perusahaan dalam melakukan pengelompokan terhadap penilaian kepuasan pelanggan berdasarkan kategori sangat puas, puas, tidak puas dan netral, penelitian dilakukan sampai pada pengelompokan tingkat kepuasan pelanggan dengan hasil penilaian dari skala linkert, pada sistem tidak diterapkan metode dalam pengukuran dan hasil rekomendasi atau perbaikan yang perlu dilakukan oleh perusahaan.

Penelitian [10] Kepuasan pelanggan merupakan suatu evaluasi spesifik terkait dengan kualitas pelayanan yang diberikan oleh perusahaan kepada pelanggan, tidak terlepas halnya dari dunia pendidikan, kepuasan pelanggan yang merupakan mahasiswa adalah suatu target dari Univeritas yang ingin dicapai, Politeknik Negeri Malang membantu Program Studi Informatika dalam mengukur tingkat kepuasan pelanggan terhadap kinerja pelayanan program studi dengan penerapan dari metode importance performance analysis dalam menentukan prioritas perbaikan pada layanan kinerja, penerapan sistem informasi dan metode pengukuran terhadap tingkat kepuasan dapat dilakukan dengan cepat, efisien dan dan keakuratan dalam pengolahan data dan informasi.

Penelitian [11] Pengukuran kepuasan pelanggan yang dilakukan pada Universitas Mataram merupakan salah satu upaya yang dilakukan Universitas dalam memperbaiki kinerja layanan administrasi yang diberikan pada mahasiswa, penerapan sistem informasi pada audit kepuasan pelanggan membantu setiap program studi untuk mengetahui tingkat kepuasan mahasiswa terhadap kinerja, data hasil dari pengisian kuesioner diolah dengan menggunakan metode importance performance analysis dimana penilaian dilakukan dengan skala linkert, hasil dari penelitian diperoleh tingkat kepuasan pada masing-masing program studi berada pada kategori cukup puas, penerapan teknologi informasi pada survey kepuasan membantu pengelolaan data menjadi lebih cepat dan dapat digunakan secara berkelanjutan apabila diterapkan secara konsisten.

Penelitian [12] Tingginya tingkat kepuasan pelanggan menunjukan baiknya kinerja yang dilakukan oleh perusahaan untuk memenuhi kebutuhan pelanggan, evaluasi yang dilakukan melalui audit kepuasan pelanggan diharapkan mampu untuk memahami permasalahan yang timbul dalam proses pemberian layanan kepada pelanggan, seperti halnya pengukuran kepuasan pelanggan pada pasien. Puskesmas

$$
\text { p-ISSN:1693 - 2951; e-ISSN: 2503-2372 }
$$


Baros yang dilakukan untuk mengetahui tingkat kepuasan pasien dan kualitas layanan yang diberikan maka dilakukan audit kepuasan pasien dengan menggunakan suatu teknologi informasi yang dikombinasikan dengan metode customer satisfaction index untuk melakukan pengukuran terhadap kepuasan pasien dan kualitas, hasil dari penelitian ini yaitu sistem informasi yang dibuat memberikan kemudahan pada pasien dalam memberikan penilaian kepuasan pelanggan, dengan penerapan metode pada sistem menghasilkan suatu nilai persentase tingkat kepuasan pelanggan yang dapat diterima secara cepat, dalam penanganan permasalahan perbaikan dengan tingkat kepuasan yang rendah belum dapat direkomendasikan melalui sistem.

Penelitian [13] Pengelolaan data hasil audit kepuasan pelanggan secara cepat dan efisien akan membantu perusahaan untuk mendapatkan hasil dari tingkat kepuasan secara cepat dan mudah, penelitian terkait dengan penerapan teknologi informasi pada audit kepuasan pelanggan dilakukan oleh PT. Usaha Saudara Mandiri Tangerang untuk mempermudah customer service yang menangani dalam survey kepuasan pelanggan untuk mengolah data dan menganalisa keluhan pelanggan, hasil dari penelitian penerapan teknologi informasi dapat mempercepat proses analisa kepuasan pelanggan dengan hasil dari survey yang berupa visualisasi grafik, pada sistem tidak diterapkan metode dalam mengukur kepuasan pelanggan, sehingga tidak diketahui tingkat pengukuran kepuasan pelanggan yang dilakukan.

Penelitian [14] Penerapan teknologi informasi pada audit kepuasan pelanggan memiliki kelebihan untuk membantu perusahaan dalam efisiensi pengukuran secara cepat, dengan kemudahan akses yang diberikan maka mempercepat informasi untuk dapat diterima oleh perusahaan, penggunaan teknologi informasi berbasis mobile dilakukan pada survey kepuasan salah satu perusahaan kendaraan untuk mengukur tingkat kepuasan pelanggan secara jelas dan cepat dengan menerapkan metode customer satisfaction index hasil dari penelitian diperoleh tingkat pengukuran kepuasan pelanggan dengan persentase diatas $80 \%$ untuk penilaian kepuasan, kemudahaan akses yang diberikan oleh sistem membantu pelanggan dalam menyampaikan keluhan pelanggan tanpa perlu mengisi lembar survey dan memudahkan perusahaan dalam melakukan pengukuran tingkat kepuasan pelanggan.

Penelitian [15] Kepuasan pelanggan tidak hanya diukur pada perusahaan berbasis komersil, beberapa penyedia layanan publik melakukan pengukuran kepausan pelanggan untuk menilai tingkat kepuasan pengunjung terhadap fasilitas yang diberikan, penerapan teknologi informasi berbasis website pada survey kepuasan pelanggan yang dilakukan pada perpustakaan daerah Kota Salatiga memberikan kemudahan pengunjung untuk menyampaikan aspirasi terhadap fasilitas yang disediakan dan perbaikan yang diharapkan pada perpustakaan, pengelolaan data dengan metode servqual membantu perpustakaan dalam menilai kepuasan pelanggan kedalam beberapa dimensi sehingga perbaikan yang dilakukan pada berfokus pada dimensi yang memiliki tingkat kepuasan terendah.

Penelitian [16] Audit kepuasan pelanggan memiliki dampak yang cukup besar dalam perkembangan perusahaan sehingga perbaikan yang perlukan terhadap keluhan yang muncul diharapkan dapat diatasi dengan secepat mungkin, pengukuran kepuasan pelanggan juga dilakukan oleh pusat perbelanjaan / departmen store PT. Matahari Departmen Store Blue Plaza Bekasi yang bertujuan untuk mengetahui kualitas layanan yang diberikan kepada pengunjung oleh perusahaan dan untuk meningkatkan pengunjung, hasil dari penelitian diperoleh penerapan teknologi informasi berbasis website membantu customer service dalam mengukur kepuasan pelanggan, dengan penerapan metode servqual dalam pengukuran diperoleh tingkat kepuasan pelanggan berdasarkan dimensi pengukuran dan perbaikan yang dilakukan dapat ditentukan berdasarkan tingkat keluhan pelanggan, hal ini membantu perusahaan dalam meningkatkan kepuasan pelanggan dan mengatasi keluhan pelanggan secara cepat.

Penelitian [17] Audit kepuasan pelanggan merupakan suatu proses evaluasi yang dapat dilakukan oleh perusahaan untuk memperbaiki proses bisnis dengan mengetahui efektifitas kinerja perusahaan melalui tingkat kepuasan pelanggan, dengan penerapan sistem dalam survey kepuasan pelanggan dan pengukuran dengan metode servqual proses audit kepuasan pelanggan menjadi lebih mudah dan efektif, hasil dari penelitian diperoleh klasifikasi terhadap tingkat kepuasan pelanggan melalui mekanisme penilaian GAP pelayanan yang diberikan dan harapan pelanggan, pengukuran dengan menggunakan metode servqual membantu perusahaan dalam mengindikasikan perbaikan yang diperlukan berdasarkan dimensi penilaian sehingga tindakan perbaikan yang diambil sesuai dengan tingkat rendahnya kepuasan pelanggan pada dimensi pelayanan.

Penelitian [18] Pada pemberian pelayanan yang terbaik kepada pelanggan diperlukan suatu proses penilaian yang tepat dan jelas, proses penilaian dengan menerapkan suatu teknologi informasi pada survey kepuasan pelanggan diharapkan membantu program studi dalam melakukan pengukuran kepuasan pelanggan yang selama ini telah berjalan dengan proses secara manual penyebaran kuesioner yang dapat menimbulkan risiko duplikasi data dan data hilang karena kurangnya media penyimpanan, penerapan sistem pada survey pengukuran kepuasan pelanggan akan membantu dalam mengurangi media dalam penyebaran kusioner dan duplikasi data kuesioner .

Penelitian [19] Kemudahan akses yang diberikan dengan penerapan sistem survey kepuasan pelanggan juga dilakukan pada pengukuran kepuasan pengunjung perpustakaan, sistem informasi berbasis website yang diterapkan memberikan kemudahan kepada pengunjung untuk melakukan penilaian fasilitas perpustakaan dan kinerja pelayanan, dari hasil penelitian penerapan teknologi informasi membantu perpustakaan dalam menghemat biaya yang ditimbulkan dalam audit kepuasan pelanggan dan hasil dari survey kepuasan pelanggan dengan metode audit membantu perusahaan dalam pengukuran permaslahan tingkat kepuasan sehingga perbaikan difokuskan kepada indikator penilaian yang memiliki nilai terendah dalam kepuasan pelanggan sesuai dengan dimensi pengukuran.

Penelitian [20] Proses audit kepuasan akan berhasil dilakukan apabila data yang disebarkan dapat dikirim kembali dan dilengkapi sesuai dengan instrument penilaian yang diinginkan, penerapan teknologi informasi pada audit 
kepuasan pelanggan pada PT. Pupuk Kalimantan Timur bertujuan untuk memastikan pengisian data kuesioner dan kembalinya data hasil survey kepuasan pelanggan sebagai bahan dalam evaluasi perusahaan dalam peningkatan kinerja perusahaan, hasil dari penelitian yang dilakukan penerapan teknologi informasi berbasis website memberikan kemudahan dalam proses survey audit kepuasan pelanggan dan hasil dari survey dapat dikumpulkan dengan waktu yang singkat dengan membutuhkan sedikit tenaga.

Penelitian [21] Penerapan teknologi informasi dalam proses audit kepuasan pelanggan yang diterapkan pada RSUD Syarifah Ambani Ratu Ebu Bangkalan yang dengan menerapkan metode servqual serta perhitungan pendukung keputusan simple addictive weighting membantu perusahaan dalam pengelolaan data hasil survey dan memberikan informasi kepada rumah sakit terkait dengan tingkat kinerja pelayanan rumah sakit secara mudah serta rekomendasi tindakan perbaikan prioritas yang harus dilakukan pada beberapa poli yang dimiliki oleh rumah sakit, penerapan teknologi informasi dalam proses audit memberikan kemudahan dalam proses pengumpulan dan pengolahan data serta proses analisa sehingga dapat mengemat waktu dan biaya untuk menghasilkan inforamasi dan rekomendasi perbaikan kinerja perusahaan.

Penelitian [22] Penerapan teknologi informasi pada audit kepuasan pelanggan untuk pengukuran tingkat layanan management administrasi Universitas Catur Insan Cendekia Cirebon memberikan kecepatan bagi pemangku kepentingan dalam mengambil keputusan untuk perbaikan kinerja layanan management, dengan merapkan sebuah metode customer satisfaction index dalam pengukuran terhadap kinerja pelayanan menjadi lebih terarah sehingga perbaikan yang perlu dilakukan dapat difokuskan kepada harapan pelanggan terhadap kinerja pelayanan.

Penelitian [23] Audit kepuasan pelanggan apabila dilakukan secara manual akan menghabiskan biaya dan waktu yang cukup besar karena hasil yang dikelola oleh pihak ketiga yang memiliki risiko dalam memanipulasi hasil dari survey kepuasan pelanggan yang dilakukan secara manual, oleh sebab itu penerapan teknologi informasi dilakukan pada audit kepuasan pelanggan perusahaan PDAM Surya Sembada Kota Surabaya dilakukan untuk menanggulangi hal tersebut, dari hasil penelitian diperoleh implementasi dari survey kedalam sebuah teknologi informasi dapat berjalan dengan baik, penerapan fitur yang dibutuhkan dapat diimplementasikan kedalam sebuah sistem dan digunakan oleh pelanggan secara baik. Dari hasil penerapan teknologi ini dapat meminimalkan adanya ketidakakuratan dalam proses audit kepuasan pelanggan.

Penelitian [24] Audit terhadap kepuasan pengguna suatu produk atau jasa merupakan salah satu bentuk pengukuran kepuasan pelanggan terhadap layanan kinerja penyedia, hasil yang diperoleh dari audit kepuasan pelanggan tentunya akan digunakan sebagai acuan perbaikan kinerja sehingga proses bisnis bisa berjalan sesuai dengan harapan pelanggan, hasil yang akurat dan independen akan membantu perusahaan dalam melakukan perbaikan secara tepat sasaran dan cepat sehingga perbaikan yang dilakukan akan memberikan dampak berkelanjutan. Hasil dari penerapan teknologi Charolina Devi Oktaviana S: Literature Review Penerapan ... informasi, metode IPA serta CSI yang diterapkan dalam proses audit kepuasan pelanggan pada aplikasi learning management system menghasilkan suatu nilai tingkat kepuasan dan skala prioritas perbaikan yang pada system berdasarkan tingkat kepentingan ketersediaan fitur tersebut yang dilakukan oleh mahasiswa, hasil audit yang mudah diperoleh membantu universitas dalam memperbaiki kinerja sistem untuk pembelajaran selanjutnya.

Penelitian [25] Audit kepuasan pelanggan juga dilakukan oleh universitas terhadap alumni yang telah bekerja, hal ini dilakukan untuk mengukur kemampuan Universitas dalam menghasilkan alumni dan memastikan sebaran dari alumni yang telah bekerja pada perusahaan, dari hasil penelitian penerapan teknologi informasi berbasis website pada survey kepuasan stakeholder terhadap kinerja alumni diperoleh persentase kepuasan sebesar $67 \%$ responden merasa sangat puas terhadap sistem yang digunakan untuk melakukan penilaian karena sistem yang dikembangkan dapat dibuka kapan saja dan dimana saja sehingga memberikan kemudahan bagi para stakeholder memberikan penilaian kepuasan.

Penelitian [26] Penerapan teknologi informasi pada pengukuran kepuasan pelanggan membantu perusahaan untuk mendapatkan hasil penilaian kepuasan pelanggan terhadap produk yang dihasilkan oleh perusahaan, penggunaan teknologi informasi dalam survey kepuasan pelanggan secara online juga dilakukan oleh PT. Inter Maju Terus dalam melakukan pengukuran kepuasan, hasil yang diperoleh dari penelitian ini menunjukan pengukuran dengan penggunaan teknologi informasi dengan menerapkan skala penilaian linkert mempermudah dalam penyebaran kuesioner dan pengumpulan data, hasil pengukuran yang diperoleh dapat diterima dengan cepat dan sebagai bahan tolak ukur perusahaan dalam melakukan perbaikan, dapat memaksimalkan dalam penyebaran daerah penjualan produk dengan kemudahan penyebaran kuesioner.

Penelitian [27] Penerapan teknologi informasi dalam survey kepuasan memiliki kelebihan dibandingkan dengan melakukan pengisian kuesioner secara manual, hasil penerapan e-kuesioner kepuasan pelanggan PT. PLN (Persero) Rayon Tegal Timur menunjukan adanya pengurangan penggunaan media kertas dalam penyebaran kuesioner, percepatan dalam pengumpulan data kuesioner dan kemudahan yang diberikan dalam pengisian kuesioner karena aplikasi yang dikembangkan berbasis website dengan fitur yang mudah untuk digunakan, pengukuran kepuasan pelanggan yang dilakukan dengan mengukur tingkat kepuasan pelanggan menggunakan penilaian skala linkert.

Penelitian [28] Kepuasan pelanggan merupakan salah satu indikator dari keberhasilan pelayanan, sama halnya dengan audit kepuasan pasien pada Rumah Sakit Daerah Madani, tinggi atau rendahnya tingkat kepuasan pasien adalah suatu penilaian terhadap kinerja perawat, Berdasarkan hasil penelitian penerapan teknologi informasi berbasis mobile pada proses audit memudahkan pasien dalam menyampaikan penilaian kepuasan, teknologi informasi berbasis mobile yang diterapkan dapat menilai tingkat kepuasan pasien terhadap kinerja perawat, sehingga RSD

p-ISSN:1693 - 2951; e-ISSN: 2503-2372 
Madani dapat melakukan penilaian terhadap kinerja perawat terbaik berdasarkan pada tingkat kepuasan pasien.

Penelitian [29] Pengetahuan karyawan terhadap pengelolaan operation dan maintenance dalam bidang pemasangan dan pemeliharaan jaringan Telco Calling Card dapat ditingkatkan dengan mengetahui indeks kepuasan masyarakat terhadap kepuasan layanan yang diberikan, Audit kepuasan masyarakat terhadap layanan dengan menerapkan metode IPA berbasis website diterapkan untuk membantu Perusahaan dalam memperbaiki kualitas layanan. Berdasarkan hasil penelitian penerapan teknologi informasi pada pengukuran kepuasan pelanggan mempermudah dalam memperoleh hasil kepuasan pelanggan secara cepat dan akurat, dimana data hasil dari kepuasan pelanggan dapat diolah secara otomatis sehingga operation dan maintenance dapat dengan cepat untuk melakukan perbaikan pada keluhan ketidakpuasan layanan.

Penelitian [30] Pola dari kepuasan pelanggan merupakan salah satu informasi yang dapat digunakan sebagai strategi perusahaan dalam pengambilan keputusan pada proses perbaikan layanan, Audit kepuasan pelanggan yang digunakan untuk mengetahui pola kepuasan pelanggan dengan menerapkan metode CSI yang dilakukan pada $E$ Commerce Model Business to Customer menjadi salah satu fitur tambahan, menghasilkan suatu kemudahan bagi pemilik layanan website e-commerce dalam mendapatkan indeks kepuasan pengguna dalam meningkatkan layanan dan bahan evaluasi dalam pengembangan website.

Penelitian [31] Penggunaan metode pada teknologi informasi audit kepuasan pelanggan akan memudahkan perusahaan dalam mengolah data hasil survey kepuasan dan mengetahui tingkat kepuasan layanan. Penerapan teknologi informasi berbasis website pada survey kepuasan membantu PT. PLN (Persero) Area Jember untuk mengetahui indeks kepuasan pelanggan dengan menerapkan metode servqual pada proses audit dan selanjutnya dilakukan klasifikasi terhadap tingkat kepuasan dengan metode K-Means Clustering. Berdasarkan hasil penelitian diperoleh tingkat akurasi perhitungan dengan penerapan teknologu informasi dan metode audit mencapai $100 \%$, dan hasil dari proses audit dapat digunakan pengambilan keputusan perbaikan pada proses layanan.

Beberapa studi literature terkait dengan penerapan teknologi informasi dalam melakukan audit kepuasan pelanggan telah dilakukan dengan rata- rata hasil penelitian yang diperoleh adanya kemudahan dalam penyebaran kuesioner dan pengumpulan data hasil pengukuran sehingga membantu perusahaan dalam melakukan pengolahan data secara cepat. Rekapitulasi hasil dari studi literature ditunjukan pada Tabel I.

TABEL. I

REKAPITULASI LITERARTURE REVIEW PENERAPAN TEKNOLOGI INFORMASI DAN METODE PENGUKURAN KEPUASAN PELANGGAN

\begin{tabular}{|c|c|c|c|c|}
\hline No & Penelitian & $\begin{array}{c}\text { Teknologi } \\
\text { Informasi }\end{array}$ & Metode & $\begin{array}{c}\text { Rekomendasi } \\
\text { Manual / } \\
\text { Otomatis }\end{array}$ \\
\hline 1 & $\begin{array}{c}\text { Penelitian } \\
{[8]}\end{array}$ & Website & PROMETHEE & Otomatis \\
\hline 2 & $\begin{array}{c}\text { Penelitian } \\
{[9]}\end{array}$ & Website & - & Manual \\
\hline
\end{tabular}

\begin{tabular}{|c|c|c|c|c|}
\hline 3 & $\begin{array}{c}\text { Penelitian } \\
{[10]}\end{array}$ & Website & IPA & Otomatis \\
\hline 4 & $\begin{array}{c}\text { Penelitian } \\
\text { [11] }\end{array}$ & Website & IPA & Otomatis \\
\hline 5 & $\begin{array}{c}\text { Penelitian } \\
{[12]}\end{array}$ & Website & CSI & Otomatis \\
\hline 6 & $\begin{array}{c}\text { Penelitian } \\
{[13]}\end{array}$ & Website & CSI & Otomatis \\
\hline 7 & $\begin{array}{c}\text { Penelitian } \\
\text { [14] }\end{array}$ & Mobile & CSI & Otomatis \\
\hline 8 & $\begin{array}{c}\text { Penelitian } \\
\text { [15] }\end{array}$ & Website & Servqual & Otomatis \\
\hline 9 & $\begin{array}{c}\text { Penelitian } \\
{[16]}\end{array}$ & Website & Servqual & Otomatis \\
\hline 10 & $\begin{array}{c}\text { Penelitian } \\
{[17]}\end{array}$ & Website & Servqual & Otomatis \\
\hline 11 & $\begin{array}{c}\text { Penelitian } \\
{[18]}\end{array}$ & Website & - & Manual \\
\hline 12 & $\begin{array}{c}\text { Penelitian } \\
{[19]}\end{array}$ & Website & Servqual & Manual \\
\hline 13 & $\begin{array}{c}\text { Penelitian } \\
{[20]}\end{array}$ & Website & - & Manual \\
\hline 14 & $\begin{array}{l}\text { Penelitian } \\
\text { [21] }\end{array}$ & Website & Servqual & Otomatis \\
\hline 15 & $\begin{array}{c}\text { Penelitian } \\
{[22]}\end{array}$ & Website & CSI & Otomatis \\
\hline 16 & $\begin{array}{c}\text { Penelitian } \\
\text { [23] }\end{array}$ & Website & - & Manual \\
\hline 17 & $\begin{array}{c}\text { Penelitian } \\
\text { [24] }\end{array}$ & Website & IPA \& CSI & Otomatis \\
\hline 18 & $\begin{array}{c}\text { Penelitian } \\
{[25]}\end{array}$ & Website & - & Manual \\
\hline 19 & $\begin{array}{c}\text { Penelitian } \\
{[26]}\end{array}$ & Website & - & Manual \\
\hline 20 & $\begin{array}{c}\text { Penelitian } \\
\text { [27] }\end{array}$ & Website & - & Manual \\
\hline 21 & $\begin{array}{c}\text { Penelitian } \\
{[28]}\end{array}$ & Mobile & - & Manual \\
\hline 22 & $\begin{array}{c}\text { Penelitian } \\
\text { [29] }\end{array}$ & Website & IPA & Otomatis \\
\hline 23 & $\begin{array}{c}\text { Penelitian } \\
{[30]}\end{array}$ & Website & CSI & Otomatis \\
\hline 24 & $\begin{array}{c}\text { Penelitian } \\
\text { [31] }\end{array}$ & Website & Servqual & Otomatis \\
\hline
\end{tabular}

\section{B. Tinjauan Penelitian}

Hasil dari penelitian yang telah dilakukan sebelumnya menunjukan adanya perbedaan dalam sejauh mana peranan teknologi informasi pada audit kepuasan pelanggan, dari beberapa studi literature yang dilakukan diperoleh data hasil penerapan teknologi informasi dibandingkan penerapan teknologi informasi dengan metode penelitian, ditunjukan Gambar 3. 


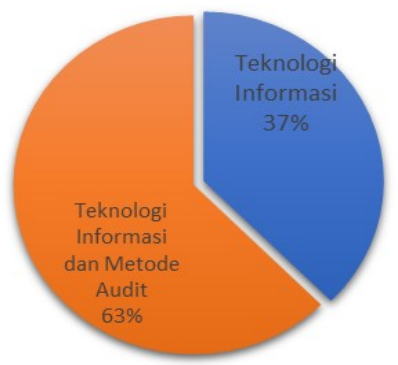

Gambar 3: Grafik Penerapan Teknologi Informasi

Dari data hasil penelitian menunjukan penerapan teknologi informasi yang dikombinasikan dengan metode audit memiliki presentase lebih tinggi yaitu 63\%, Pada penelitian yang dilakukan menujukan beberapa kelebihan yang dimiliki selama proses audit apabila teknologi informasi dikombinasikan dengan metode pengukuran, ditunjukan pada Tabel II.

TABEL. II

KELEBIHAN PENERAPAN TEKNOLOGI DAN METODE PENGUKURAN KEPUASAN PELANGGAN

\begin{tabular}{|c|l|}
\hline No & \multicolumn{1}{|c|}{ Kelebihan } \\
\hline 1 & $\begin{array}{l}\text { Penentuan tingkat kepuasan pelanggan dapat } \\
\text { diklasifikasikan berdasarkan dimensi penilaian } \\
\text { pengukuran sehingga hasil kepuasan pelanggan } \\
\text { dapat lebih terarah. }\end{array}$ \\
\hline 2 & $\begin{array}{l}\text { Hasil dari pengisian survey dapat diolah secara } \\
\text { langsung untuk menghindari faktor human error }\end{array}$ \\
\hline 3 & $\begin{array}{l}\text { Membantu perusahaan dalam menentukan } \\
\text { prioritas perbaikan. }\end{array}$ \\
\hline 4 & $\begin{array}{l}\text { Kemudahan akses untuk perusahaan dalam } \\
\text { mendapatkan informasi hasil pengolahan } \\
\text { kepuasan pelanggan secara cepat. }\end{array}$ \\
\hline 5 & $\begin{array}{l}\text { Mengurangi waktu tunggu, biaya dan } \\
\text { penggunaan kertas yang diperlukan dalam } \\
\text { proses pengolahan data }\end{array}$ \\
\hline 6 & $\begin{array}{l}\text { Menghindari risiko duplikasi data dan } \\
\text { mengurangi penggunaan media penyimpanan } \\
\text { data. }\end{array}$ \\
\hline 7 & $\begin{array}{l}\text { Efisiensi dan efektifitas dalam melakukan } \\
\text { penyebaran kuesioner serta pengumpulan data } \\
\text { hasil survey. }\end{array}$ \\
\hline
\end{tabular}

Penerapan teknologi informasi memberikan kemudahan dalam proses audit, sehingga setiap tahapan dapat terdokumentasi dan tersimpan secara terstruktur. Penggunaan media dalam penyebaran kuesiner berbasis teknologi dibagi menjadi dua jenis yaitu website dan mobile, tingkat penggunaan berdasarkan penelitian ditunjukanpada Gambar 4

Charolina Devi Oktaviana S: Literature Review Penerapan ...

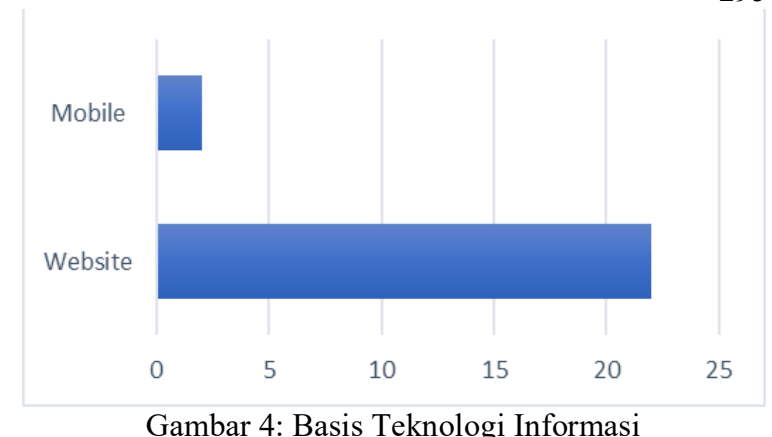

Gambar 4 menunjukan teknologi informasi berbasis website masih lebih unggul digunakan dibandingkan dengan teknologi informasi berbasis mobile, hal ini disebabkan penggunaan teknologi informasi berbasis website lebih mudah diakses dan diterapkan pada organisasi yang memilki basis data yang besar, dengan adanya teknologi informasi pada audit kepuasan mempermudah perusahaan dalam melakukan tahapan dalam proses audit, dari penerapan teknologi informasi pada proses audit terdapat beberapa penelitian yang menerapkan metode dalam pengukuran, metode yang paling banyak diterapkan pada sistem audit kepuasan pelanggan ditunjukan pada Gambar 5.

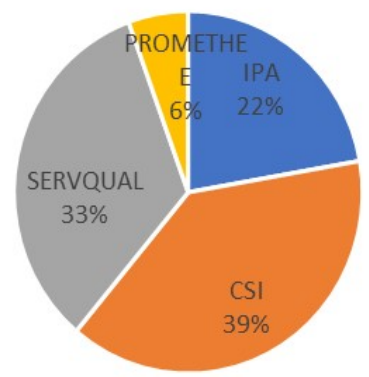

Gambar 5: Metode Audit Kepuasan Pelanggan

Gambar 5 menunjukan penggunaan metode pengukuran customer satusfaction index (CSI) memiliki nilai presentase penggunaan tertinggi yaitu sebesar 39\% dari metode lainnya, pada hasil studi literature penelitian diketahui metode CSI memiliki beberapa keunggulan ditunjukan pada Tabel III.

TABEL. III

Kelebihan PENERAPAN Metode CSI

\begin{tabular}{|c|l|}
\hline No & $\begin{array}{l}\text { Kelebihan Metode Customer Satisfaction Index } \\
\text { (CSI) }\end{array}$ \\
\hline 1 & $\begin{array}{l}\text { Membantu perusahaan dalam menentukan } \\
\text { perbaikan menjadi lebih terarah pada dimensi } \\
\text { pengukuran yang dibutuhkan perusahaan }\end{array}$ \\
\hline 2 & $\begin{array}{l}\text { Memiliki metode perhitungan yang mudah } \\
\text { diterapkan }\end{array}$ \\
\hline 3 & $\begin{array}{l}\text { Memperhatikan tingkat kepentingan setiap atribut } \\
\text { yang digunakan dalam pengukuran. }\end{array}$ \\
\hline
\end{tabular}

Penerapan teknologi informasi dan metode pengukuran pada audit kepuasan pelanggan memiliki kelebihan dalam

p-ISSN:1693 - 2951; e-ISSN: 2503-2372 
menghasilkan suatu nilai yang dapat digunakam sebagai tolak ukur kinerja perusahaan, dengan penelitian ini penulis akan menggunakan teknologi informasi berbasis website yang dikombinasikan dengan metode pengukuran untuk mengasilkan suatu sistem pendukung keputusan dalam perbaikan kinerja perusahaan, dimana hasil dari audit kepuasan pelanggan akan digunakan untuk menentukan tindakan perbaikan sehingga dapat meningkatkan produktivitas proses bisnis. Berikut agenda penelitian disajikan pada Gambar 6.

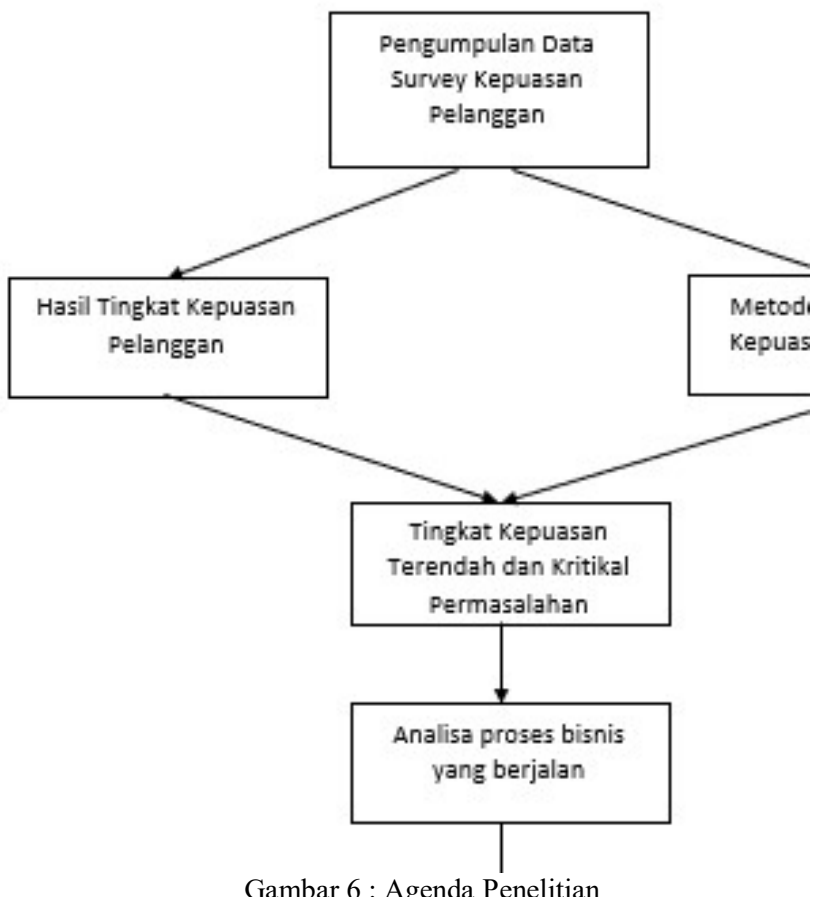

Gambar 6 menunjukan hasil akhir yang diharapkan dari penelitian yang dilakukan yaitu untuk mengukur tingkat kepuasan pelanggan dan permasalahan kritikal yang muncul pada proses bisnis dengan menerapkan teknologi informasi berbasis website dan metode pengukuran sehingga menghasilkan suatu sistem pendukung keputusan untuk pengambilan keputusan dalam perbaikan kinerja perusahaan.

\section{KESIMPULAN}

Studi literature dari penerapan teknologi informasi dan metode pengukuran pada audit kepuasan pelanggan menunjukan hasil sebagai berikut :

1. Keterbatasan studi literature dilakukan berdasarkan 24 dokumen pada mesin pencarian google scholar yang berkaitan dengan penerapan teknologi dan metode audit pada audit kepuasan pelanggan.

2. Sebanyak $92 \%$ teknologi informasi berbasis website lebih banyak digunakan dibandingkan dengan mobile karena mudah untuk diakses oleh pelanggan dimanapun dan kapanpun.

3. Sebesar $63 \%$ penggunaan Teknologi informasi disertai dengan penerapan metode audit lebih banyak diterapkan pada proses audit kepuasan pelanggan.
4. Penggunaan metode pengukuran pada penerapan teknologi informasi membantu akan perusahaan untuk memperoleh hasil survey kepuasan pelanggan secara cepat tanpa memerlukan biaya tambahan dalam pengolahan data.

5. Hasil dari pengukuran dapat digunakan sebagai bahan pertimbangan perbaikan keluhan pelanggan karena dapat diklasifikasikan lebih terarah.

6. Sebanyak $39 \%$ penelitian terkait penerapan teknologi informasi dan metode pada audit kepuasan menggunakan metode customer satisfaction index.

\section{REFERENSI}

[1] Putri, Y. L. "Pengaruh Kualitas Pelayanan Terhadap LoyaLitas Pelanggan dengan kepuasan sebagai variable intervening". Among Makarti, 10(19), 70-90. 2017.

[2] Firmansyah, D., \& Prihandono, D. (2018). "Pengaruh Kualitas Pelayanan Dan Perceived Value Terhadap Loyalitas Pelanggan Dengan Kepuasan”. Management Analysis Journal, 7(1) 2018.

[3] Afif, M., Labib, M., Wibawa. "Analisis Peta Kompetitor Industri Mobile Payment di Indonesia". Jurnal Sains Dan Seni Its, 8(1). 2019.

[4] Umam, R. K., \& Hariastuti, N. P. "Analisis kepuasan pelanggan dengan menggunakan metode Customer Satisfaction Index (CSI) dan Importance Performance Analysis (IPA)". Seminar Nasional Sains Dan Teknologi Terapan, 339-344, 2018.

[5] Kotler, Philip, "Manajemen Pemasaran Analysis Perencanaan dan Implementasi ", Salemba Empat, Jakarta.

[6] Darmaastawan, K., Oka Saputra, K., \& Ary Esta Dewi Wirastuti, N. M.. Optimasi Peran Desa Adat di Bali melalui Teknologi Informasi. Majalah Ilmiah Teknologi Elektro, 20(1), 161. 2021.

[7] Putra, I. B. A. E. M., Hartati, R. S., \& Divayana, Y. Audit Sistem Informasi E-Kinerja Dinas Kependudukan Dan Pencatatan Sipil Kota Denpasar. Majalah Ilmiah Teknologi Elektro, 19 (1), 107. 2020.

[8] Gusrianty, Oktarina, D., dan Kurniawan, W. J., "Sistem Pendukung Keputusan Dengan Metode Promethee Untuk Menentukan Kepuasan Pelanggan Penjualan Sepeda Motor Bekas," Sistemasi, vol. 8, hal: 62-69, Jan. 2019.

[9] Iriani, A., Manuputty, A. D., dan Patty, W. G. I., "Sistem Informasi Kepuasan Pelanggan Terhadap Tabungan Mutiara (Studi Kasus : PT. Bank Maluku)," Jurnal Sistem Informasi, vol. 5, hal: 17-36, Mar. 2010.

[10] Ikrawan, Z., Ariyanto, Y., \& Harijanto, B. (2017). Sistem Informasi Pengukuran Kepuasan Pelanggan Menggunakan Metode Importance Performance Analysis Pada Program Studi Manajemen Informatika. Jurnal Informatika Polinema, 1(4), 48.

[11] Syaifullah, Wijaya, I. G. P. S., dan Husodo, A. Y., "Sistem Informasi Kepuasan Layanan Administrasi Akademik Berbasis IPA (Important Performance Analysis) Studi Kasus Fakultas Teknik Universitas Mataram," Journal of Computer Science and Informatics Engineering (J-Cosine), vol. 2, hal: 37-43, Jun. 2018.

[12] Sastradipraja, C. K., dan Barokah, R. A., "Rancang Bangun Sistem Informasi Kualitas Layanan Terhadap Kepuasan Pasien Menggunakan Metode Customer Satisfaction Index," Jurnal Ilmiah Flash, vol. 6, hal: 16-27, Des. 2020.

[13] Hernawati, dan Yani, A., "Sistem Informasi Survei Kepuasan Pelanggan Berbasis Web Pada PT. Usaha Saudara Mandiri Tangerang," Jurnal Inovasi dan Sains Teknik Elektro (INSANtek), vol. 1, hal: 108-115, Nov. 2020.

[14] Khusna L., "Aplikasi Survei Kepuasan Pelanggan Berbasis Android Menggunakan Metode Customer Satisfaction Index (CSI) Pada Ahass Handayani Semarang (skripsi)," Universitas Negeri Semarang, 2020.

[15] Saputra, P. A., dan Nugroho, A., "Perancangan Dan Implementasi Survei Kepuasan Pengunjung Berbasis Web Di Perpustakaan Daerah 
Majalah Ilmiah Teknologi Elektro, Vol. 20, No. 2, Juli-Desember 2021

DOI: https://doi.org/10.24843/MITE.2021.v20i02.P13

Kota Salatiga,’ Jurnal Ilmiah Teknologi Informasi, vol. 15, hal: $63-$

71, Jan. 2017.

[16] Satria, "Analisis Sistem Informasi Mengukur Kepuasan Pelayanan Pelanggan Dengan Metode Servqual,” Jurnal Kilat, vol. 8, hal: 52-64, Apr. 2019.

[17] Hendrawan, N., et al, "Rancang Bangun Aplikasi Survey Kepuasan Pelanggan Terhadap Kinerja Pelayanan PDAM Kab. Bombana Menggunakan Metode Servqual," Jurnal Informatika, vol. 9, hal: 3039, Jun. 2020

[18] Octariadi, B. C., dan Syaibah, "Sistem Informasi Kepuasan Mahasiswa Terhadap Pelayanan Administrasi Pada Program Studi Teknik Informatika Universitas Muhammadiyah Pontianak,' Cybernetics, vol. 3, hal: 64-71, Nov. 2019.

[19] Suwarti, "Perancangan Aplikasi Survei Kepuasan Pengunjung Perpustakaan Berbasis Web Studi Kasus : AMIK Tri Dharma Pekanbaru," Jurnal Informatika, Manajemen dan Komputer, vol. 10 hal: 21-25, Des. 2017.

[20] Azhari, A. R., Brata, A. H., dan Brata, K. C., "Pengembangan Sistem Survei Pelanggan Berbasis Website (Studi Kasus : Departemen Pemasaran Urea PT. Pupuk Kalimantan Timur)," Jurnal Pengembangan Teknologi Informasi dan Ilmu Komputer, vol. 9, hal: 9257-9263, Sept. 2019.

[21] Putro, S. S., Rahmanita, E., dan Isnaniyah, R. S., "Implementasi Metode Servqual Dan SAW Untuk Analisa Kepuasan Pasien Berdasarkan Kualitas Pelayanan Poli Rawat Jalan," Jurnal Komunikasi, Media dan Informatika, vol. 6, hal: 1-9, Agu. 2017.

[22] Amri, H. R., Subagio, R. T., dan Kusnadi, "Penerapan Metode CSI Untuk Pengukuran Tingkat Kepuasan Layanan Manajemen," Jurnal Sistem Cerdas, vol. 3, hal: 241-252, 2020.

[23] Islami, A. N. F., Aknuranda, I. and Perdanakusuma, A. R., "Pengembangan Sistem Survei Kepuasan Pelanggan Pada PDAM Surya Sembada Kota Surabaya," Jurnal Pengembangan Teknologi Informasi dan Ilmu Komputer, vol. 2, hal: 1690-1697, Apr. 2018

[24] Sinnun, A., "Analisis Kepuasan Pengguna LMS Berbasis Web Dengan Metode Servqual, IPA, dan CSI," Jurnal Informatika, vol. 4, Shal: 146-154, Apr. 2017

[25] Anggraini, W., Prabowo, N. A., \& Arumi, E. R.. Perancangan dan Implementasi Survei Kepuasan Stakeholder Alumni Berbasis Web. Techno.Com, 19(1), 24-33. Feb. 2020

[26] Hendry Hendry, Y. H. Perancangan Sistem Informasi Pengisian Kuesioner Secara Online untuk Mengukur Kepuasan Pelanggan Terhadap. Jurnal Ilmiah Core IT, 6(2) 2018.

[27] Afriliana, I., Munadia, H., \& Hasta, I. D. (2018). EKUPEL: EKuesioner Kepuasan Pelanggan Pada PT. PLN (Persero) Rayon Tegal Timur. Jurnal ICT: Information Communication \& Technology, 17(1), 28-33. 2018.

[28] Efendi, Y., Swastikarini, S. (2020). Aplikasi Survey Kepuasan Pasien Terhadap Pelayanan Perawat Berbasis Mobile. J-SAKTI, 4, September, 397-404. 2020.

[29] Silalahi, I., Aelani, K., \& Juliane, C. (2020). Implementasi Metode Importance Performance Analysis (IPA) untuk Pengukuran Indeks Kepuasan Masyarakat (IKM) terhadap Pelayanan Administrasi di Kecamatan Gedebage berbasis Web. Journal of Information Technology, 2(2), 55-60.

[30] Widodo, S. M., \& Sutopo, J. (2018). Metode Customer Satisfaction Index (CSI) Untuk Mengetahui Pola Kepuasan Pelanggan Pada Ecommerce Model Business to Customer. Jurnal Informatika Upgris, 4(1), 38-45.

[31] Rochman, R. S., Retnani, W. E. Y., \& Juwita, O. (2020). Rancang Bangun Aplikasi Analisis Indeks Kepuasan Pelanggan pada PT. PLN (PERSERO) Area Jember dengan Menggunakan Pendekatan Metode Servqual dan K-Means Clustering. Berkala Sainstek, 8(3), 96.

Charolina Devi Oktaviana S: Literature Review Penerapan ... 
\{ Halaman ini sengaja dikosongkan \} 